\title{
Influence of e-HRM and Human Resources Service Quality on Employee Performance
}

\author{
N. NURLINA ${ }^{1}$, Jubair SITUMORANG ${ }^{2}$, Muhammad AKOB ${ }^{3}$, Cici Aryansi QUILIM $^{4}$, Aryati ARFAH ${ }^{5}$ \\ Received: July 21, 2020 Revised: August 23, 2020 Accepted: September 03, 2020
}

\begin{abstract}
This study aims to analyze the relationship of e-HRM implementation to employee performance both directly and indirectly through the intervening of the Human Resource service Quality variable, both practically and theoretically. This study uses variance-based structural equation modeling (SEM) techniques with partial least square (PLS) statistical testing tools to test the direct relationship of e-HRM and the performance and relationship moderated by Human Resources service quality tested on 200 civil servants in five offices under the coordination of the Government of the South Sulawesi Province of Indonesia. The data collection model in this study uses an online survey. The data analysis stages through the explanatory concept consist of, first, the interpretation of the distribution of the average frequency of respondents' answers; second, outer-loading; third, determination of the validity and reliability; fourth, the coefficient of determination test and partial test; fifth, the GoF model; sixth, validity test; and seventh, hypothesis testing. This study explores four hypotheses in a comprehensive fashion; the results of this study show that all hypotheses have positive and significant effects both through direct and intervening relationships. Among the three direct relationships, the relationship of e-HRM variables on HR Service Quality is greatest and most dominant.
\end{abstract}

Keywords: e-HRM, Human Resources Management, Service-Quality, Employee Performance

JEL Classification Code: L25, L84, M54, O15

\section{Introduction}

Technology has become an essential part of our daily lives, including in the work environment (Naveed et al., 2019). Technology has also become a core part of the

${ }^{1}$ First Author and Corresponding Author. Associate Professor, Department of Management, STIMI YAPMI, Makassar, Indonesia [Postal Address: Perintis Kemerdekaan Street, Biringkanaya, Makassar City, South Sulawesi Province, 90241, Indonesia]

Email: yapmi.nurlina@gmail.com

${ }^{2}$ Associate Professor, Faculty of Sharia and Islamic Economics, Department Sharia, IAIN Ternate, Ternate City, North Maluku, Indonesia.

${ }^{3}$ Associate Professor, Postgraduate Management Program, STIEM Bongaya, Makassar City, South Sulawesi, Indonesia.

${ }^{4}$ Associate Professor, Faculty of Sharia and Islamic Economics, Department of Islamic Economics, IAIN Ternate, Ternate City, North Maluku, Indonesia.

${ }^{5}$ Associate Professor, Faculty of Economics and Business, Department of Management, Universitas Muslim Indonesia, Makassar City, South Sulawesi, Indonesia.

(c) Copyright: The Author(s)

This is an Open Access article distributed under the terms of the Creative Commons Attribution Non-Commercial License (https://creativecommons.org/licenses/by-nc/4.0/) which permits unrestricted non-commercial use, distribution, and reproduction in any medium, provided the original work is properly cited. process of accelerating organizational growth (Alibekova et al., 2019; Lee \& Xuan, 2019). The world has become more sophisticated, dynamic, and uncertain in the era of globalization due to technology (Kwan et al., 2019). Organizations must improve their competitiveness to be more innovative than their competitors to achieve a competitive advantage (Esther et al., 2019; Lestari et al., 2020; Hoang \& Ngoc, 2019). The agility to adapt to rapid global competition and changes in aspects of technology and human resources is one of the most important features to survive and continue to run the business sustainably (Florkowski, 2018; Haerani et al., 2020). The human resources department requires a combination of human resource (HR) and technology based on information systems to penetrate competition. The help of technology systems enables HR professionals to provide better services, reduce administrative burdens, and provide stakeholders with access to data-based information. For example, the number of recruitment documents, which consume a lot of time and place, can be replaced by digital files (Alfes et al., 2013; Jeannette et al., 2019). Indeed, there is a transformation of HRM activities from manual to automatic behavior by using technology designed to overcome solutions to various problems encountered (Marler \& Parry, 2016). The implementation of technology in human 
resource management (HRM) activities is also known as Electronic Human Resources Management (e-HRM). The application of e-HRM in organizations can promote sustainability because it reduces negative environmental, social, and economic consequences (Florkowski, 2018).

Research in the HRM field has long been conducted based on quantitative survey data, supplemented by qualitative interviews and case data (de Leeuw et al., 2016). Now e-HRM has become a new strategy for companies in running their business (Arian et al., 2019), The utilization of IT becomes a vital role in carrying out the functions of human resource management. But on the other hand, research on e-HRM produces contradictory findings namely whether e-HRM that has been realized has a significant impact (Fersht. P, 2016). Several studies have shown that HR has benefited from companies that adopt e-HRM, organization can save costs and improve efficiency (Naveed et al., 2019), also provides flexible services and increases employee participation (Sharna, 2019). Related to this Bondarouk (2011) assumes that e-HRM enables HR professionals to measure organizational performance and improve their company's position among competitors and consumers. Even e-HRM is also considered as a tool to assist managers in making strategic decisions (Chierici et al., 2019).

This research expands on the workings of e-HRM and focuses on the direct impact of e-HRM on employee performance and the indirect effect on performance mediated by the quality of HRM services on performance (Ross et al., 2017). e-HRM allows employees to carry out HR-related activities more comfortably; they tend to perceive it as a sufficient HR Service Quality (Heikkilä et al., 2017), and have more time for other work. There is still little research that addresses this relationship. (Marler \& Parry, 2016). Kathleen et al (2017) state that studies on e-HRM have been carried out in the context of developed European and US economies, and paid little attention to differences in social settings. Indonesia's South Sulawesi provincial government agency uses individual e-HRM practices with a system that has improved sharply. Top management focuses on HR quality that allows researchers to assess the relationship between e-HRM and employee performance. Objectively, this study aims to analyze the relationship of e-HRM implementation on employee performance both directly and indirectly through the intervening variable of Human Resource service Quality (QHRS). It is hoped that this study can provide managerial implications both in the practice of Human Resource Management governance that is integrated with the use of information systems, as well as being an organizational strategy to improve employee performance. The theoretical implications are also the goal of this study, so that the development of management science for students in the field of management is growing.

\section{Literature Review and Hypothesis Development}

e-HRM research needs to be expanded and deepened (Bondarouk et al., 2011) by combining a list of phenomena that arise and how e-HRM is being implemented and used in large companies, primarily global firms (Huub et al., 2011). However, e-HRM can be narrowly defined as administrative support of the HR function within an organization using Internet (Gardner et al., 2003). On the other hand, this definition only covers technological factors in e-HRM. This research also deals with changes in the content and positioning of the HR function, which runs parallel to the introduction of e-HRM technology. A multi-factorial framework for studying e-HRM is preferred, which includes several factors such as new technology, organization, work design, organizational context, and HRM strategies and policies. Bondarouk et al (2011) states that the level of acceptance and assimilation by employees to adopt e-HRM is a fundamental factor for the successful application of e-HRM. The ability to deal with changes in HR functions and current problems, and the attitude towards e-HRM given to employees during the implementation of e-HRM is also considered important (Kathleen et al., 2017). However, there is little empirical knowledge of the attitudes of concurrent employees during e-HRM implementation. Furthermore, changes in the roles that HR fulfills in the organization and implementation of e-HRM are related to each other, and should not be considered separately (Gardner et al., 2003). Therefore, the hypothesis in this study reads:

H1: e-HRM has a positive and significant effect on employee performance.

One type of e-HRM system that is commonly adopted is known as workforce management. Workforce management tools used to help find the right person, with the right skills, in the right place, at the right time, and at the correct cost (Sierra-Cedar, Inc, 2015). These solutions usually include functions such as time and attendance, scheduling, budgeting and forecasting, absence and leave management, and analysis (Sierra-Cedar, Inc, 2015). As one specific type of e-HRM system, this workforce management application can cover the full spectrum of e-HRM objectives, including operational, relational, and transformational perspectives (Marler \& Parry, 2016). From an operational perspective, workforce management can help make many of these processes more efficient. From a relational point of view, the human resource department might provide better services to organizations using labor management (Ramdani et al., 2014). The transformational perspective is perhaps best represented by the tendency to use more sophisticated 
analytics to understand and more effectively use of labor (Lal, 2015; Chulanova et al., 2019).

Esther et al (2019) say that to improve the performance gains from implementing transformational e-HRM in organizations, HR managers need access to available artificial intelligence productivity tools. The use of information systems-based technology has a positive impact on improving the quality of services in human resources management. Improved performance is the achievements and dreams expected by all organizations. The annexation of information systems as a tool to enhance the quality of HR services enables the realization of labor efficiency to enhance the competitiveness of companies (Aryee et al., 2016). Companies often introduce e-HRM to enable HR and other employees to focus on more essential tasks in valueadding activities (Nivlouei, 2014).

Previous research has shown that the e-HRM system can improve processes and HR that influence strategic outcomes (Bondarouk et al., 2011). As a result, the quality of HR services becomes an essential proposition in the causal chain of performance in implementing e-HRM. Uen et al (2012) argue that the quality of HR services must be evaluated through a framework of various inputs, processes, and outputs. The output of HR service quality illustrates the consequences of service quality and shows what the organization is achieving by providing quality service to employees. If HR services meet the needs of employees, their productivity tends to increase. The quality HR service process links the factors that influence the perception of HR service quality with the consequences of perceived HR service quality, such as interaction and collaboration (Uen et al., 2012). Incorporating HR services represents the structure, practices, technology, resources, and equipment to support services. The literature shows that human resource management practices that are welldesigned and well-established structures are significant to improve the quality of HR services (Gardner et al., 2003: Marler \& Parry, 2016).

Values should have been set in terms of efficiency and quality of human resource services so that business performance is healthy (Marler \& Fisher, 2013). The quality of HR services has proven to be an essential factor that creates value for employees. One reason why companies use e-HRM is to improve the quality of their HR services to employees (Kathleen et al., 2017). Companies have recognized the importance of improving the quality of HR services they provide and focus on performance to enhance their sustainable competitive advantage (Bondarouk et al., 2011). The perception of the quality of HR services can increase employee satisfaction and, as a result, how managers perceive improved employee performance (Aryee et al., 2016). The quality of HR services refers to the expectations of improving the quality of HRM services through e-HRM (Bondarouk, 2011). This can improve the quality of services that HR provides to employees; companies might improve their performance (Marler \& Parry, 2016). Therefore, the hypotheses in this study are an interlinking of variables such as:

H2: e-HRM has a positive and significant effect on $H R$ service quality

H3: HR service quality has a positive and significant effect on employee performance

H4: e-HRM, through the intervening relationship to HR service quality, has a positive and significant effect on employee performance

\section{Research Methods and Materials}

The sampling technique used in the study is purposive sampling based on Sarstedt et al (2011). A total of 200 online questionnaires were distributed to government officials in five departments in the province of South Sulawesi, Indonesia. This study uses structural equation modeling (SEM) technique to empirically examine the relationship of e-HRM to employee performance, and intervening HR quality service variables to see the indirect effect using SmartPLS software. Stages of testing in this study include the Cronbach's Alpha value $>0.60$; AVE $>060$; Composite reliability $>0.60$ total item correlations, and confirmatory factor analysis to test the reliability, convergent validity and discriminant validity for each construct of the conceptual framework. This study also uses a 5-point Likert scale that refers to studies on e-HRM developed by Bissola and Imperatori (2013) This research focuses on nine items related to e-HRM: (1) performance management; (2) performance appraisal; (3) benefit management; (4) recruitment; (5) selection; (6) training and development; (7) complaints management; (8) talent management; and (9) knowledge management.

Furthermore, this study uses the perception of HR service quality and employee performance as endogenous variables. Based on Kathleen et al (2017) and (Bondarouk, 2011) in the quality of HR services, we measure Human Resource Service-Quality (QHRS) using six items based on Naveed et al. (2019): (1) perceived quality of HR services; (2) the e-HRM system guarantees administration without error; (3) services are carried out correctly and appropriately; (4) e-HRM improves the quality of HR services; (5) e-HRM can complete the manager's task quickly; and (6) HR services have met the organization's standardization. Finally, we use managers' perceptions of employee performance when analyzing the relationship between e-HRM and employee performance. Besides, other studies (Naveed et al., 2019) 
have used the perception of performance on the basis that it is a valid and reliable measure based on Ahmad and Allen (2015) study, which is based on five items, taken from the literature, namely, (1) employee absence; (2) employee presentations; (3) quality and quantity of work; (4) task productivity; and (5) innovation productivity. The stages of testing include, first, the interpretation of the average frequency distribution of respondents' answers (mean, standard error, standard deviation); second, the outer-loading item where the loading factor $>0.60$; third, determining the validity and reliability (Cronbach's Alpha, composite reliability, AVE) $>0.60$; Fourth, testing the coefficient of determination (R2) as well as the partial test (F2); fifth, testing the Goodness of fit of the model (GoF); sixth, testing the discriminant validity where the coefficient value $>0.60$; seventh, testing the hypothesis directly or indirectly. The hypothesis test criteria are Constant Boostraping $(\mathrm{n}=200)$ with Sig. level $<0.05$.

\section{Results and Discussion}

\subsection{Statistics Results}

Table 1 describes the characteristics of the sample.

Table 1: Data Respondent $\mathrm{n}=200$

\begin{tabular}{|l|c|c|}
\hline Gender & $\mathbf{n}$ & $\mathbf{\%}$ \\
\hline Male & 100 & 50 \\
\hline Female & 100 & 50 \\
\hline Age (Years) & $\mathrm{n}$ & $\%$ \\
\hline $20-30$ & 44 & 22 \\
\hline $31-40$ & 73 & 36,5 \\
\hline $41-50$ & 61 & 30,5 \\
\hline$\geq 51$ & 22 & 11 \\
\hline Education & $\mathrm{n}$ & $\%$ \\
\hline Diploma & 26 & 13 \\
\hline Bachelor & 141 & 71 \\
\hline Magister & 31 & 16 \\
\hline Doctoral & 2 & 1 \\
\hline Length of work (Years) & $\mathrm{n}$ & $\%$ \\
\hline $1-5$ & 12 & 6 \\
\hline $6-10$ & 61 & 31 \\
\hline $11-15$ & 100 & 50 \\
\hline $16-20$ & 15 & 8 \\
\hline$>21$ & 12 & 6 \\
\hline
\end{tabular}

Table 2 describes the stages of testing the validity and reliability of data; for example, in the e-HRM variable consisting of nine items (e-HRM1 - e-HRM9) states the value of loading items is overall at the level of $>0.60$; as well as items in all other variables. Specifically, on the e-HRM items, there are deleted items (e-HRM4) in the test. That is because the value of item loadings on e-HRM4 does not meet the standard value $>0.60$. While the dominant item that forms the e-HRM variable is the e-HRM7 item (loadings $=0.839$ or $83.9 \%$ ). The items forming the e-HRM variable produce the Cronbach's Alpha value $=0.913>0.60$; composite reliability $=0.929>0.60 ; \mathrm{AVE}=0.621>0.60$. Furthermore, in the QHRS variable, two items are deleted in the testing phase (QHRS1 and QHRS2), the dominant item forming the QHRS variable is QHRS5 (loading = 0.844). Cronbach's Alpha value on the QHRS variable is $0.795>0.60$; composite reliability of $0.866>0.60$; AVE of $0.618>0.60$. Finally, at the stage of testing the validity and reliability of the data on employee performance variables where the EP2 item (loading $=0.842$ ) is the most dominant item forming the dependent variable. The Cronbach's Alpha value on the variable employee performance is equal to $0.836>0.60$; composite reliability of $0.883>0.60$; AVE of $0.603>0.60$.

The R-square values of the two dependent variables (i.e., Employee performance and e-HRS) show values of 0.675 and 0.612 . R-Square determination coefficient value is assumed that the role of e-HRM as a determinant factor on the employee performance variable is $67.5 \%$. The determination of the e-HRM variable on the e-HRS variable is $61.2 \%$. So, the difference from the percentage value of the two dependent variables is in the range of $40 \%$ employee performance variables, and e-HRS variables are influenced by variables other than eHRM. The f-square value describing the partial relationship between e-HRM and employee performance is 0.205 (20.5\%); eHRS on employee performance is $0.247(24.7 \%)$. Overall, the collinearity value (VIF) is at a normality level $<10$. Then, in the Goodness of Fit test model, which is also in Table 2, shows that the model has met the eligibility test requirements. The discriminant validity testing also interprets that the overall validity of the variables is above $>0.60$.

\subsection{Hypothesis Results}

Table 3 presents the hypothesis testing in which all tests support positive and significant influence both through direct and indirect relationships. Among the three direct relationships, the relationship between the e-HRM variables on QHRS was the most influential relationship $(t=28,656>$ 1.96). Illustrations of the effects of variables are also shown in Figure 1. 
Tabel 2: Statistics Results

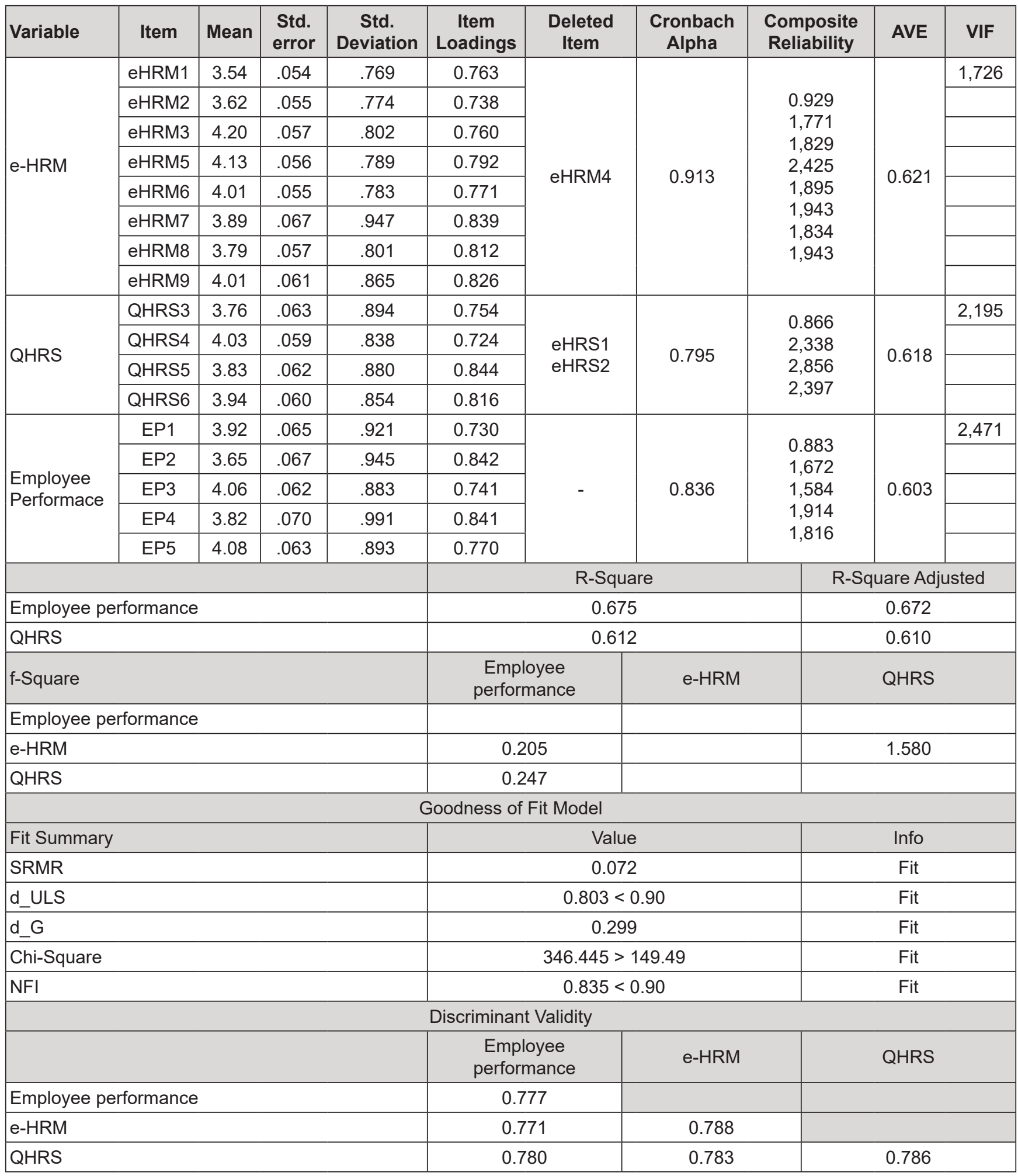


Table 3: Hypotheses Results

\begin{tabular}{|l|c|c|c|c|c|}
\hline \multicolumn{7}{|c|}{ Direct Effect } \\
\hline & $\begin{array}{c}\text { Sample } \\
\text { Mean }\end{array}$ & $\begin{array}{c}\text { Standard } \\
\text { Deviation }\end{array}$ & T-Statistics & P-Value & Info \\
\hline e-HRM $\rightarrow$ Employee Performance & 0.419 & 0.068 & 6.119 & $<0.01$ & Support \\
\hline e-HRM $\rightarrow$ QHRS & 0.783 & 0.027 & 28.656 & $<0.01$ & Support \\
\hline QHRS $\rightarrow$ Employee Performance & 0.452 & 0.066 & 6.877 & $<0.01$ & Support \\
\hline \multicolumn{7}{|c|}{ Specific Indirect Effect } \\
\hline e-HRM $\rightarrow$ QHRS $\rightarrow$ Employee performance & 0.354 & 0.053 & 6.778 & $<0.01$ & Support \\
\hline
\end{tabular}

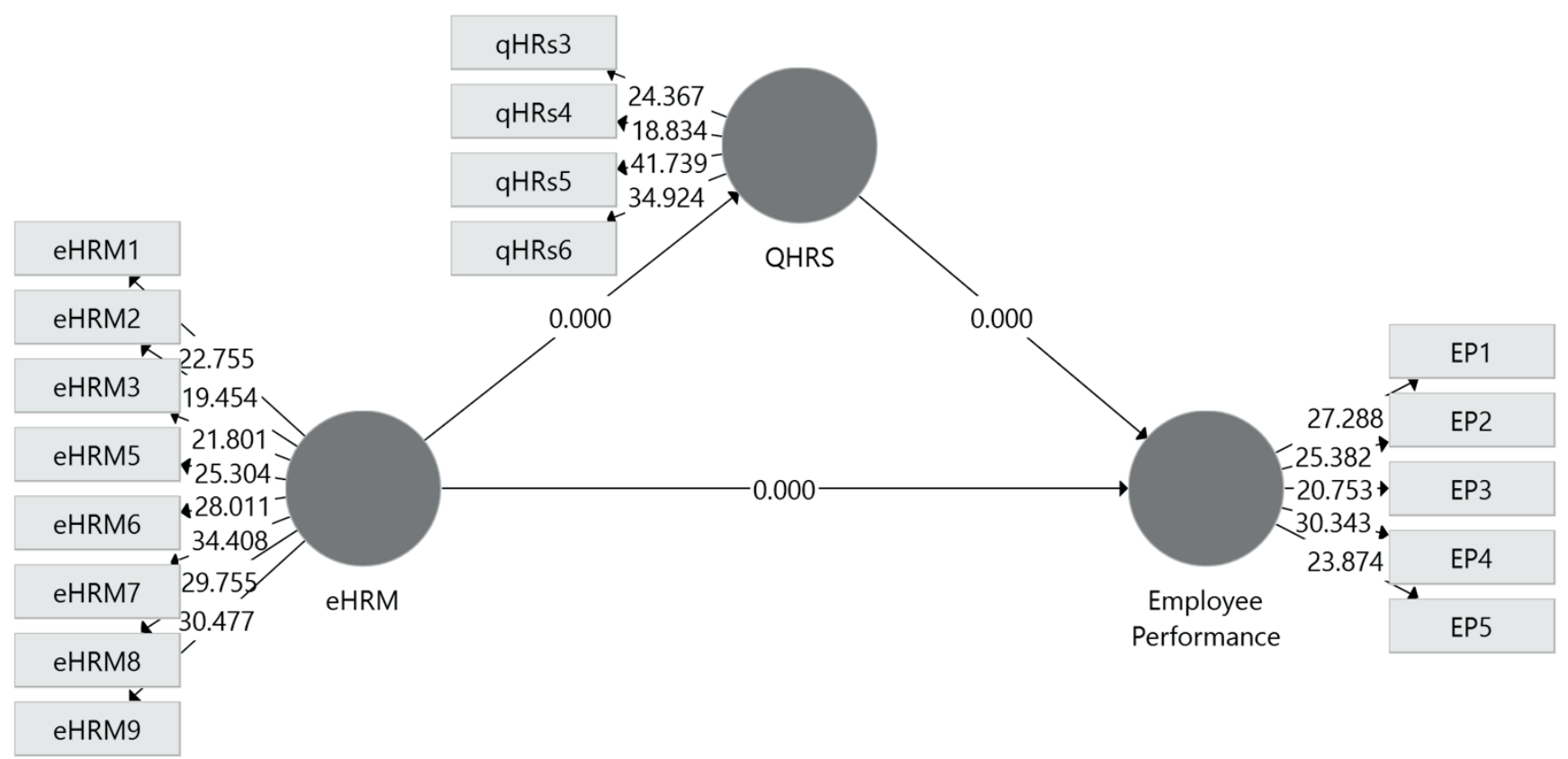

Figure 1: Hypotheses Result

\subsection{Discussion}

This study discusses the implementation of e-HRM as the main factor in driving employee performance. To overcome the lack of previous research, this study proposes and tests directly the relationship of e-HRM with employee performance, where this study includes HR service quality as an intervening variable to examine more deeply the implementation of e-HRM on the success or driver of employee performance. In this case, we developed and tested our first hypothesis, different from the majority of empirical research (e.,g., Allen, 2015; Naveed et al., 2019; Zhou, Fey, \& Yildiz, 2020). Our results indicate that the implementation of e-HRM in terms of the application of performance management; performance assessment; benefits management; recruitment process; selection; training and development; and complaints management; then talent management and the management knowledge used by managers have positive and significant results on employee performance. These results are in line with research conducted by Naveed et al (2019), where the empirical results generated in testing e-HRM on the performance of Bank employees in Pakistan showed positive and significant results. On the other hand, implementing e-HRM is not always easy for the company. On the other hand, in the application of e-HRM, it is not always easy for managers to use e-HRM to improve their ability to recruit and manage human resources (Marler \& Fisher, 2013).

However, without clearly understanding the value proposition of e-HRM, managers can undoubtedly estimate the overall impact of e-HRM implementation on the organization, or it may also affect employees. This 
research has shown that e-HRM and the quality of HR services have a significant influence on improving employee performance. Therefore, HR managers must ensure that they design the e-HRM system correctly to support the organization's workflow. In particular, managers must focus on the impact of e-HRM on the quality of HR services holistically (Bondarouk et al., 2017). Because this is the stage where e-HRM can improve employee performance, this study argues that the introduction of e-HRM alone is not enough to improve employee performance or organizational performance; companies will benefit only if e-HRM helps employees carry out their various tasks faster or easier (Bondarouk et al., 2016).

Furthermore, this study also found that effective use of the performance appraisal system improves employees' ability. This shows that the effective implementation of e-HRM in the workforce management process can optimally make employees work well. All hypotheses are supportive of performance, including intervening in the quality of HR services. Of course, this is a fact that managers need a high level of creativity and must be innovative in implementing e-HRM because it is indispensable to make changes and adjustments in improving employee performance with the e-HRM system (Lin, 2011). Quality of service is very dependent on three things, namely, systems, technology, and people. The human factor holds the most significant contribution so that service quality is more difficult to imitate than product quality and price. One factor that determines the level of success and quality of an organization is its ability to provide services to customers. An organization's success in delivering quality services to its customers, achieving a high market share, and increasing company profits is mostly determined by the approach used. The consequences of the service quality approach of a product are essential for the company's strategy to defend itself and achieve success in the face of competition. Service quality can be realized through meeting the needs and desires of customers and the accuracy of delivery to meet customer expectations. Quality of service must start from customer needs and end with customer satisfaction and perception of service quality, as a party that consumes services that assess the company's level of service quality. Finally, based on a variety of available research, we hope that further research can develop broader and sharper concepts regarding the implementation of e-HRM to improve both employee and organizational performance, of course, with a deeper understanding of the e-HRM phenomenon that has been applied by several companies. Therefore, this study only contributes to the literature on the role of HRM practices in developing employee absorption (Bondarouk, 2011), and identify more specific HRM practices that can be adopted to develop different dimensions of absorption in the company.

\section{Conclusion}

In line with the reform of the organization's governance management system and the system for creating human resource management for the sake of having high integrity, the process of moving the governance that was formerly manual to electronic in the realm of personnel administration activities provides concrete evidence that the implementation of e-HRM is urgent. The role of information systems implemented in human resource management also has a positive impact on services that will later be provided to users. Therefore, e-HRM can be seen as an alternative way to implement the Human Resources Management strategy. Policies and practices in organizations that are mutually integrated in the system involve two factors so that e-HRM can be applied, namely, the readiness and full support of all organizational resources and the will rather than the internal organization itself. Apart from that, e-HRM is also a facility for management and employees to be more effective and efficient in measuring organizational performance and reducing the effects of cost bias.

Nevertheless, this study has certain limitations; first, it only focuses on analyzing the relationship between e-HRM implementation and performance. But the different dimensions of absorptive capacity in the context of a growing and multi-perspective economy need to be explored in depth. Second, the model that we developed is limited to compiling employees' correspondence on the implementation of e-HRM activities. However, the nature of these relationships can change at certain stages. It can develop into a more complex picture to allow for several different points of view, especially if viewed from organizational behavior. So, it is suggested for future research to assess aspects of the application of e-HRM involving the regulatory readiness and corporate resources in the implementation of e-HRM. Then, the intervention of e-HRM is not only reviewed to measure performance, but also employee perceptions during the application of e-HRM as part of a human resources management strategy.

\section{References}

Alfes, K., Truss, C., Soane, E. C., Rees, C., \& Gatenby, M. (2013). The relationship between line manager behavior, perceived HRM practices, and individual performance: Examining the mediating role of engagement. Human Resource Management, 52(6), 839-859. https://doi.org/10.1002/hrm.21512

Alibekova, G., Tleppayev, A., Medeni, T. D., \& Ruzanov, R. (2019). Determinants of Technology Commercialization Ecosystem for Universities in Kazakhstan. Journal of Asian Finance, Economics and Business, 6(4), 271-279. https://doi. org/10.13106/jafeb.2019.vol6.no4.271

Ahmad, M., \& Allen, M. (2015). High performance HRM and establishment performance in Pakistan: an empirical analysis, 
Employee Relations, 37(5), 506-524. https://doi.org/10.1108/ ER-05-2014-0044

Arian, R.-F., Hanna, K.-V., Janne, H., \& Harri, H. (2019). Advantages and potential challenges of data management in e-maintenance. Journal of Quality in Maintenance Engineering, 25(3), 378396. https://doi.org/10.1108/JQME-03-2018-0018

Aryee, S., Walumbwa, F. O., Seidu, E. Y. M., \& Otaye, L. E. (2016). Developing and Leveraging Human Capital Resource to Promote Service Quality: Testing a Theory of Performance. Journal of Management, 42(2), 480-499. https://doi. org/10.1177/0149206312471394

Bissola, R., \& Imperatori, B. (2013). Facing e-HRM: The consequences on employee attitude towards the organisation and the HR department in Italian SMEs. European Journal of International Management, 7(4), 450-468. https://doi. org/10.1504/EJIM.2013.055282

Bondarouk, T. (2011). Theoretical Approaches to e-HRM Implementation. In: T. Bondarouk, H. Ruël, and J. Kees Looise (Eds.), Electronic HRM in Theory and Practice (Advanced Series in Management, Vol. 8) (pp. 1-20). Bingley, UK: Emerald Group Publishing. https://doi.org/10.1108/S18776361(2011)0000008005

Bondarouk, T., Harms, R., \& Lepak, D. (2017). Does e-HRM lead to better HRM service?. International Journal of Human Resource Management, 28(9), 1332-1362. https://doi.org/10.10 $80 / 09585192.2015 .1118139$

Bondarouk, T., Schilling, D., \& Ruël, H. (2016). EHRM adoption in emerging economies: The case of subsidiaries of multinational corporations in Indonesia. Canadian Journal of Administrative Sciences, 33(2), 124-137. https://doi.org/10.1002/cjas.1376

Chierici, R., Mazzucchelli, A., Garcia-Perez, A., \& Vrontis, D. (2019). Transforming big data into knowledge: the role of knowledge management practice. Management Decision, 57(8), 1902-1922. https://doi.org/10.1108/MD-07-2018-0834

Chulanova, Z. K., Satybaldin, A. A., \& Koshanov, A. K. (2019). Methodology for Assessing the State of Human Capital in the Context of Innovative Development of the Economy: A ThreeLevel Approach. Journal of Asian Finance, Economics and Business, 6(1), 321-328. http://doi.org/10.13106/jafeb.2019. vol6.no1.321

De Leeuw, S., Minguela-Rata, B., Sabet, E., Boter, J., \& Sigurðardóttir, R. (2016). Trade-offs in managing commercial consumer returns for online apparel retail. International Journal of Operations \& Production Management, 36(6), 710731. http://doi.org/10.1108/IJOPM-01-2015-0010

Esther, N., Huub, R., Hefin, R., Linda, E., \& Michael, M. (2019). An Analysis of the Contribution of e-HRM to Sustaining Business Performance. In: HRM 4.0 For Human-Centered Organizations (Advanced Series in Management, Vol. 23) (pp. 21-39). Bingley, UK: Emerald Publishing Limited. https://doi. org/10.1108/S1877-636120190000023003

Florkowski, G. W. (2018). HR Technology Systems: An EvidenceBased Approach to Construct Measurement. In: M. R. Buckley,
A. R. Wheeler, and J. R. B. Halbesleben (Eds.), Research in Personnel and Human Resources Management (Research in Personnel and Human Resources Management, Vol. 36) (pp. 197-239). Bingley, UK: Emerald Publishing Limited. https://doi.org/10.1108/S0742-730120180000036006

Gardner, S. D., Lepak, D. P., \& Bartol, K. M. (2003). Virtual HR: The impact of information technology on the human resource professional. Journal of Vocational Behavior, 63(2), 159-179. https://doi.org/10.1016/S0001-8791(03)00039-3

Haerani, S., Sumardi, Hakim, W., Hartini, \& Putra, A. H. P. K. (2020). Structural Model of Developing Human Resources Performance: Empirical Study of Indonesia States Owned Enterprises. Journal of Asian Finance, Economics and Business, 7(3), 211-221. https://doi.org/10.13106/jafeb.2020. vol7.no3.211

Heikkilä, J.-P., Rentto, O., \& Feng, Y. (2017). Aiming for Strategic e-HRM: Motives and Consequences of e-HRM Implementation in an MNC. In: T. Bondarouk, H. J. M. Ruël, and E. Parry (Eds.), Electronic HRM in the Smart Era (The Changing Context of Managing People) (pp. 173-179). Bingley, UK: Emerald Publishing Limited. https://doi.org/10.1108/978-178714-315-920161007

Hoang, C. C., \& Ngoc, B. H. (2019). The Relationship between Innovation Capability and Firm's Performance in Electronic Companies, Vietnam. Journal of Asian Finance, Economics and Business, 6(3), 295-304. https://doi.org/10.13106/jafeb.2019. vol6.no3.295

Huub, R., Rodrigo, M., \& C., C. C. (2011). Human Resource Information Systems: An Integrated Research Agenda. In: T, Bondarouk, H. Ruël, and J. Kees Looise (Eds.), Electronic HRM in Theory and Practice (Advanced Series in Management, Vol. 8) (pp. 21-39). Bingley, UK: Emerald Group Publishing Limited. https://doi.org/10.1108/S1877-6361(2011)0000008006

Jeannette, P., Jan, K., \& Christian, K. T. (2019). Artificial intelligence (AI) and its implications for market knowledge in B2B marketing. Journal of Business \& Industrial Marketing, 34(7), 1410-1419. https://doi.org/10.1108/JBIM-10-2018-0295

Kathleen, M., Sandra, F., \& E., C. C. (2017). e-HRM Systems in Support of "Smart" Workforce Management: An Exploratory Case Study of System Success. In: T. Bondarouk, H. J. M. Ruël, and E. Parry (Eds.), Electronic HRM in the Smart Era (pp. 87108). Bingley, UK: Emerald Publishing Limited. https://doi. org/10.1108/978-1-78714-315-920161004

Kwan, F. P., Hermawan, L. R., \& Hafizhi, N. (2019). E-HRM: Pain or Gain for HRM Effectiveness. Jurnal TAM, 10(1), 22-32. [Indonesian]

Lal, P. (2015). Transforming HR in the digital era: Workforce analytics can move people specialists to the center of decisionmaking. Human Resource Management International Digest, 23(3), 1-4. https://doi.org/10.1108/HRMID-03-2015-0051

Lee, J. W., \& Xuan, Y. (2019). Effects of Technology and Innovation Management and Total Factor Productivity on the Economic Growth of China. Journal of Asian Finance, Economics and 
Business, 6(2), 63-73. https://doi.org/10.13106/jafeb.2019. vol6.no2.63

Lestari, S. D., Leon, F. M., Widyastuti, S., Brabo, N. A., \& Putra, A. H. P. K. (2020). Antecedents and Consequences of Innovation and Business Strategy on Performance and Competitive Advantage of SMEs. Journal of Asian Finance, Economics and Business, 7(6), 365-378. https://doi.org/10.13106/jafeb.2020. vol7.no6.365

Lin, L. H. (2011). Electronic human resource management and organizational innovation: The roles of information technology and virtual organizational structure. International Journal of Human Resource Management, 22(2), 235-257. https://doi.org/ $10.1080 / 09585192.2011 .540149$

Marler, J. H., \& Fisher, S. L. (2013). An evidence-based review of e-HRM and strategic human resource management. Human Resource Management Review, 23(1), 18-36. https://doi. org/10.1016/j.hrmr.2012.06.002

Marler, J. H., \& Parry, E. (2016). Human resource management, strategic involvement and e-HRM technology. International Journal of Human Resource Management, 27(19), 2233-2253. https://doi.org/10.1080/09585192.2015.1091980

Naveed, I., Mansoor, A., \& M.C., A. M. (2019). Unveiling the relationship between e-HRM, impersonal trust and employee productivity. Management Research Review, 42(7), 879-899. https://doi.org/10.1108/MRR-02-2018-0094

Nivlouei, F. B. (2014). Electronic Human Resource Management System: The Main Element in Capacitating Globalization Paradigm. International Journal of Business and Social Science, 5(2), 147-159.

Ramdani, B., Mellahi, K., Guermat, C., \& Kechad, R. (2014). The efficacy of high performance work practices in the Middle
East: evidence from Algerian firms. International Journal of Human Resource Management, 25(2), 252-275. https://doi.org/ $10.1080 / 09585192.2013 .826918$

Ross, P. K., Ressia, S., \& Sander, E. J. (2017). Spatial Design, Worker Productivity, and Well-Being, Work in the 21st Century (The Changing Context of Managing People) (pp. 3-15). Bingley, UK: Emerald Publishing Limited. https:// doi.org/10.1108/978-1-78714-577-120171001

Sarstedt, M., Henseler, J., \& Ringle, C. M. (2011). Multigroup Analysis in Partial Least Squares (PLS) Path Modeling: Alternative Methods and Empirical Results. In: M. Sarstedt, M. Schwaiger, and C. R. Taylor (Eds.), Measurement and Research Methods in International Marketing (Advances in International Marketing, Vol. 22) (pp. 195-218). Bingley, UK: Emerald Group Publishing Limited. https://doi.org/10.1108/ S1474-7979(2011)0000022012

Sharna, W. (2019). The Human-Technology Interface in Talent Management and the Implications for HRM. In: HRM 4.0 for Human-Centered Organizations (Advanced Series in Management, Vol. 23) (pp. 99-119). Bingley, UK: Emerald Publishing Limited. https://doi.org/10.1108/S1877636120190000023009

Uen, J. F., Ahlstrom, D., Chen, S. Y., \& Tseng, P. W. (2012). Increasing HR's strategic participation: The effect of HR service quality and contribution expectations. Human Resource Management, 51(1), 3-23. https://doi.org/10.1002/hrm.20467

Zhou, A. J., Fey, C., \& Yildiz, H. E. (2020). Fostering integration through HRM practices: An empirical examination of absorptive capacity and knowledge transfer in cross-border M\&As. Journal of World Business, 55(2), 0-1. https://doi. org/10.1016/j.jwb.2018.05.005 